\section{International Scientific Journal Theoretical \& Applied Science}

p-ISSN: 2308-4944 (print) e-ISSN: 2409-0085 (online)

Year: $2018 \quad$ Issue: $03 \quad$ Volume: 59

Published: $30.03 .2018 \quad$ http://T-Science.org

SECTION 2. Applied mathematics. Mathematical modeling.
Denis Chemezov

M.Sc.Eng., Corresponding Member of International Academy of Theoretical and Applied Sciences, Lecturer of Vladimir Industrial College, Russian Federation chemezov-da@yandex.ru

Svetlana Tyurina Lecturer of Vladimir Industrial College, Russian Federation swetl.tyurina2015@yandex.ru

Anzhelika Bayakina Lecturer of Vladimir Industrial College,

Russian Federation bajakina.anzhelika@yandex.ru

Tatyana Lukyanova Lecturer of Vladimir Industrial College, Russian Federation

\title{
MULTI-FACTOR EXPERIMENT TO DETERMINING OF VIBRATIONS OF STEEL PIPES INDUCED BY VORTEX OF AIR FLOW
}

Abstract: Calculated values of the Reynolds number, stability parameter, a pipe natural frequency, vortex shedding frequency of air flow and a maximum pipe length on which there are acted vibrations, characterizing strength degree of straight steel pipes of different diameters are presented in the article.

Key words: vortex, the Reynolds number, a pipe diameter, frequency, a pipe length.

Language: English

Citation: Chemezov D, Tyurina S, Bayakina A, Lukyanova T (2018) MULTI-FACTOR EXPERIMENT TO DETERMINING OF VIBRATIONS OF STEEL PIPES INDUCED BY VORTEX OF AIR FLOW. ISJ Theoretical \& Applied Science, 03 (59): 201-209.

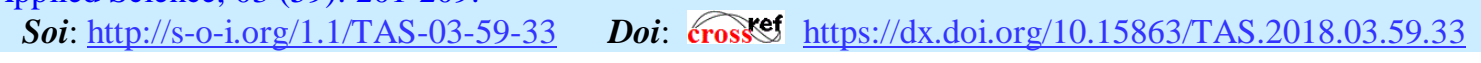

\section{Introduction}

Contact of moving fluid with local resistances leads to change of velocity and direction of flow that it is induced formation of vortex at a certain length of a pipe $[1 ; 2]$. Similar phenomenon occurs when external action of fluid flows on an outer diameter of the pipe. Herewith, in the first and the second cases, vibrations occur at the certain length of the pipe [3; 4]. Vibrations reduce strength of the pipes connection, and when coincidence of frequencies of two vibrations (natural vibrations of the pipe and vortex vibrations) there may be resonance which with more likely may lead to damage of the pipe. For recreate of real conditions of aerodynamic process, it is necessary to take into calculation the largest number of parameters. Different conditions of process of air flow on the outer diameter of the pipe are set by compilation of planning matrix of multifactor experiment [5]. Performing of multi-factor experiment will allow to assess of vibration degree of the straight steel pipes of different diameters under external action of air flows.

\section{Materials and methods}

Determining of vibrations intensity of the steel pipe induced by vortex of air flow was goal of research. Solution was performed in the special computer program based on planning matrix of multi-factor experiment. Computer experiment was performed under the following conditions:

I. Constant parameters.

1. Ratio of an inner diameter of the pipe $D$ (in) to wall thickness of the pipe $t$ (in) $-2 / 0.2,4 / 0.23$, 6/0.28, 8/0.32, 10/0.36, 12/0.37, 14/0.37, 16/0.37, $18 / 0.37,20 / 0.5$.

2. Type of fluid medium - gas (air).

3. Member elevation $-33 \mathrm{ft}$.

4. Air viscosity $v-0.000018 \mathrm{~N} \times \mathrm{s} / \mathrm{m}^{2}$.

5. Air weight density $W_{a}-0.0756 \mathrm{lb} . / \mathrm{ft}^{2}$.

6. The pipe Young's modulus $E-29000 \mathrm{ksi}$.

7. The pipe end fixity - 15.4 (fixed - pinned).

II. Variable parameters (factors).

The variable parameters of experiment were taken at high (+) and low (-) levels. $60(+)$.

1. Design wind velocity $V\left(x_{1}\right), \mathrm{mph}-10(-)$ and 


\begin{tabular}{l|lr|ll|ll} 
& ISRA (India) & $=\mathbf{1 . 3 4 4}$ & SIS (USA) & $=\mathbf{0 . 9 1 2}$ & ICV (Poland) & $=\mathbf{6 . 6 3 0}$ \\
Impact Factor: & ISI (Dubai, UAE) $=\mathbf{0 . 8 2 9}$ & PUHЦ (Russia) $=\mathbf{0 . 2 0 7}$ & PIF (India) & $=\mathbf{1 . 9 4 0}$ \\
& GIF (Australia) & $\mathbf{0 . 5 6 4}$ & ESJI (KZ) & $=4.102$ & IBI (India) & $=\mathbf{4 . 2 6 0}$ \\
& JIF & $=\mathbf{1 . 5 0 0}$ & SJIF (Morocco) & $=\mathbf{2 . 0 3 1}$ & & \\
\hline
\end{tabular}

2. Wind reference elevation $\left(x_{2}\right), \mathrm{ft}-10(-)$ and $50(+)$. $1.2(+)$.

3. The Strouhal number $S\left(x_{3}\right)[6]-0.1(-)$ and (+).

4. Material damping $\left(x_{4}\right)[7]-0.002(-)$ and 0.2

5. Safety factor $S F\left(x_{5}\right)[8]-0.2(-)$ and $1.2(+)$.

Full multi-factor experiment consists of experimental conditions which performed at different combinations of factor values. So as number of factors is 5 then for performing of multi-factor experiment it is necessary $2^{k}=2^{5}=32$ experimental conditions. $k$ in the formula is number of factors, 2 is number of levels (high and low).

Planning matrix for performing of 32 experimental conditions is presented in the table 1 .

Planning matrix of multi-factor experiment.

Table 1

\begin{tabular}{|c|c|c|c|c|c|c|}
\hline No. experimental condition & $x_{1}$ & $x_{2}$ & $x_{3}$ & $x_{4}$ & $x_{5}$ & Letter designation $^{1}$ \\
\hline 1 & 10 & 10 & 0.1 & 0.002 & 0.2 & $(-1)$ \\
\hline 2 & 60 & 10 & 0.1 & 0.002 & 0.2 & a \\
\hline 3 & 10 & 50 & 0.1 & 0.002 & 0.2 & b \\
\hline 4 & 60 & 50 & 0.1 & 0.002 & 0.2 & ab \\
\hline 5 & 10 & 10 & 1.2 & 0.002 & 0.2 & c \\
\hline 6 & 60 & 10 & 1.2 & 0.002 & 0.2 & ac \\
\hline 7 & 10 & 50 & 1.2 & 0.002 & 0.2 & bc \\
\hline 8 & 60 & 50 & 1.2 & 0.002 & 0.2 & abc \\
\hline 9 & 10 & 10 & 0.1 & 0.2 & 0.2 & d \\
\hline 10 & 60 & 10 & 0.1 & 0.2 & 0.2 & ad \\
\hline 11 & 10 & 50 & 0.1 & 0.2 & 0.2 & bd \\
\hline 12 & 60 & 50 & 0.1 & 0.2 & 0.2 & abd \\
\hline 13 & 10 & 10 & 1.2 & 0.2 & 0.2 & cd \\
\hline 14 & 60 & 10 & 1.2 & 0.2 & 0.2 & acd \\
\hline 15 & 10 & 50 & 1.2 & 0.2 & 0.2 & bcd \\
\hline 16 & 60 & 50 & 1.2 & 0.2 & 0.2 & abcd \\
\hline 17 & 10 & 10 & 0.1 & 0.002 & 1.2 & e \\
\hline 18 & 60 & 10 & 0.1 & 0.002 & 1.2 & ae \\
\hline 19 & 10 & 50 & 0.1 & 0.002 & 1.2 & be \\
\hline 20 & 60 & 50 & 0.1 & 0.002 & 1.2 & abe \\
\hline 21 & 10 & 10 & 1.2 & 0.002 & 1.2 & ce \\
\hline 22 & 60 & 10 & 1.2 & 0.002 & 1.2 & ace \\
\hline 23 & 10 & 50 & 1.2 & 0.002 & 1.2 & bce \\
\hline 24 & 60 & 50 & 1.2 & 0.002 & 1.2 & abce \\
\hline 25 & 10 & 10 & 0.1 & 0.2 & 1.2 & de \\
\hline 26 & 60 & 10 & 0.1 & 0.2 & 1.2 & ade \\
\hline 27 & 10 & 50 & 0.1 & 0.2 & 1.2 & bde \\
\hline 28 & 60 & 50 & 0.1 & 0.2 & 1.2 & abde \\
\hline 29 & 10 & 10 & 1.2 & 0.2 & 1.2 & cde \\
\hline 30 & 60 & 10 & 1.2 & 0.2 & 1.2 & acde \\
\hline 31 & 10 & 50 & 1.2 & 0.2 & 1.2 & bcde \\
\hline 32 & 60 & 50 & 1.2 & 0.2 & 1.2 & abcde \\
\hline & & & & & \\
\hline
\end{tabular}

${ }^{1}$ letters - the variable parameters only at high level, (-1) - all parameters values at low level.

\section{Results and discussion}

The ranges of numerical values of the following parameters were obtained: the Reynolds number $R_{e}-$ 15000-1100000, vortex shedding frequency $f_{v s}(\mathrm{~Hz})-$ 0.8-735.6, the maximum pipe length $L_{\max }(\mathrm{ft})-6.4-$
374.3 , the pipe natural frequency $f_{n}(\mathrm{~Hz})-0.2-882.7$, stability parameter $K_{s}-12.5-4605.8$.

The results of performed experimental conditions were mathematically processed and some of them are presented in the form of the 3D graphs. The dependencies are presented in the Fig. $1-6$ :

- the maximum pipe length from vortex shedding frequency and the Reynolds number; 


\begin{tabular}{l|lr|ll|ll} 
& ISRA (India) & $=\mathbf{1 . 3 4 4}$ & SIS (USA) & $=\mathbf{0 . 9 1 2}$ & ICV (Poland) & $=\mathbf{6 . 6 3 0}$ \\
Impact Factor: & ISI (Dubai, UAE) $=\mathbf{0 . 8 2 9}$ & PUHL (Russia) $=\mathbf{0 . 2 0 7}$ & PIF (India) & $=\mathbf{1 . 9 4 0}$ \\
& GIF (Australia) & $\mathbf{0 . 5 6 4}$ & ESJI (KZ) & $=\mathbf{4 . 1 0 2}$ & IBI (India) & $\mathbf{4 . 2 6 0}$ \\
& JIF & $=1.500$ & SJIF (Morocco) & $=\mathbf{2 . 0 3 1}$ & & \\
\hline
\end{tabular}
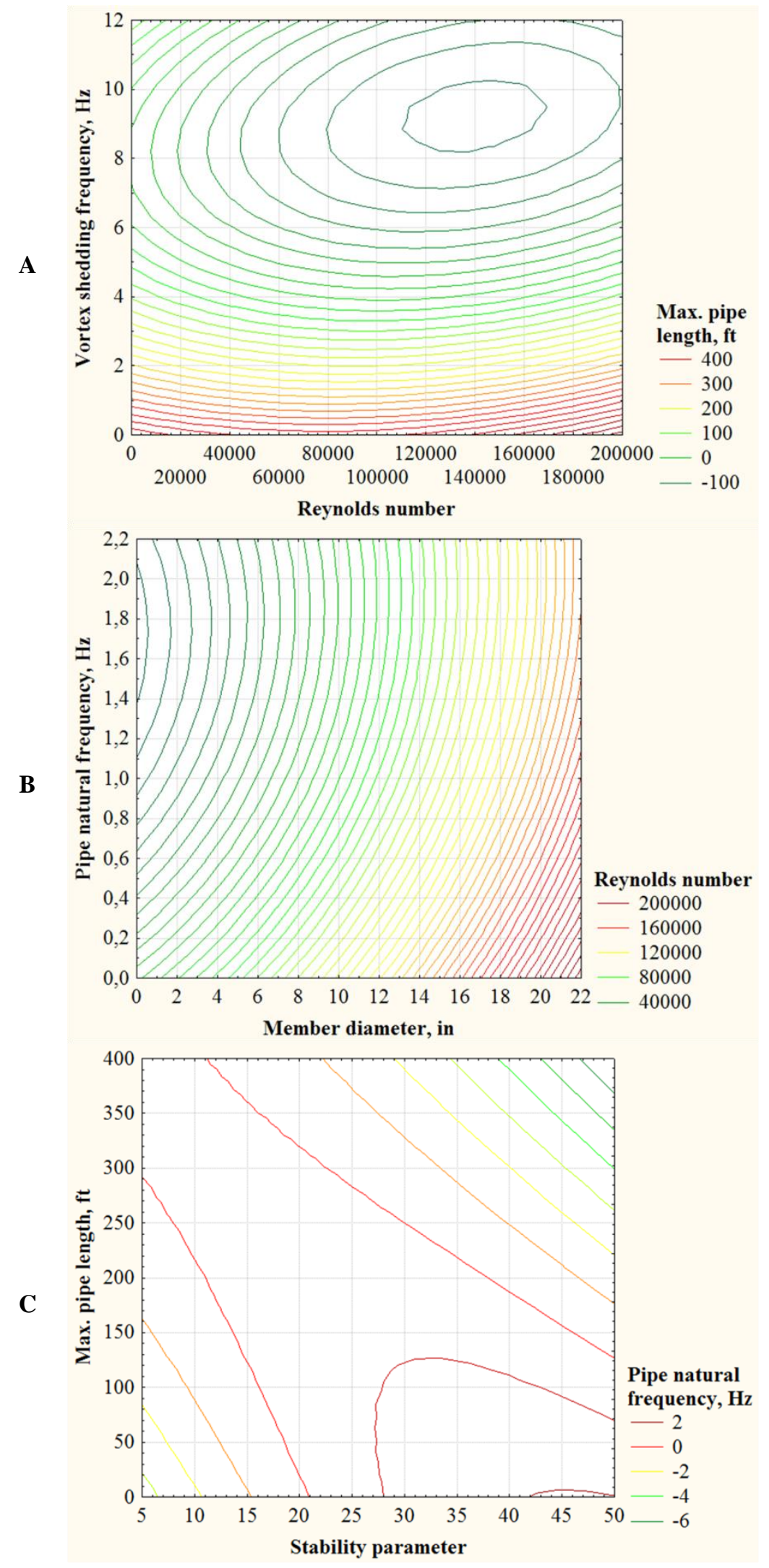

Figure 1 - Graphical representation of the results of the first experimental condition: $A$ - the dependencies of the maximum pipe length from vortex shedding frequency and the Reynolds number; $B$ - the dependencies of the Reynolds number from the pipe natural frequency and the member (pipe) diameter; $\mathrm{C}$ the dependencies of the pipe natural frequency from the maximum pipe length and stability parameter. 


\begin{tabular}{|c|c|c|c|c|c|c|}
\hline Impact Factor: & $\begin{array}{l}\text { ISRA (India) } \\
\text { ISI (Dubai, UAE } \\
\text { GIF (Australia) } \\
\text { JIF }\end{array}$ & $\begin{array}{r}=1.344 \\
=0.829 \\
=0.564 \\
=1.500\end{array}$ & $\begin{array}{l}\text { SIS (USA) } \\
\text { PИНЦ (Russia) } \\
\text { ESJI (KZ) } \\
\text { SJIF (Morocco) }\end{array}$ & $\begin{array}{l}=0.912 \\
=0.207 \\
=4.102 \\
=2.031\end{array}$ & $\begin{array}{l}\text { ICV (Poland) } \\
\text { PIF (India) } \\
\text { IBI (India) }\end{array}$ & $\begin{array}{l}=6.630 \\
=1.940 \\
=4.260\end{array}$ \\
\hline
\end{tabular}
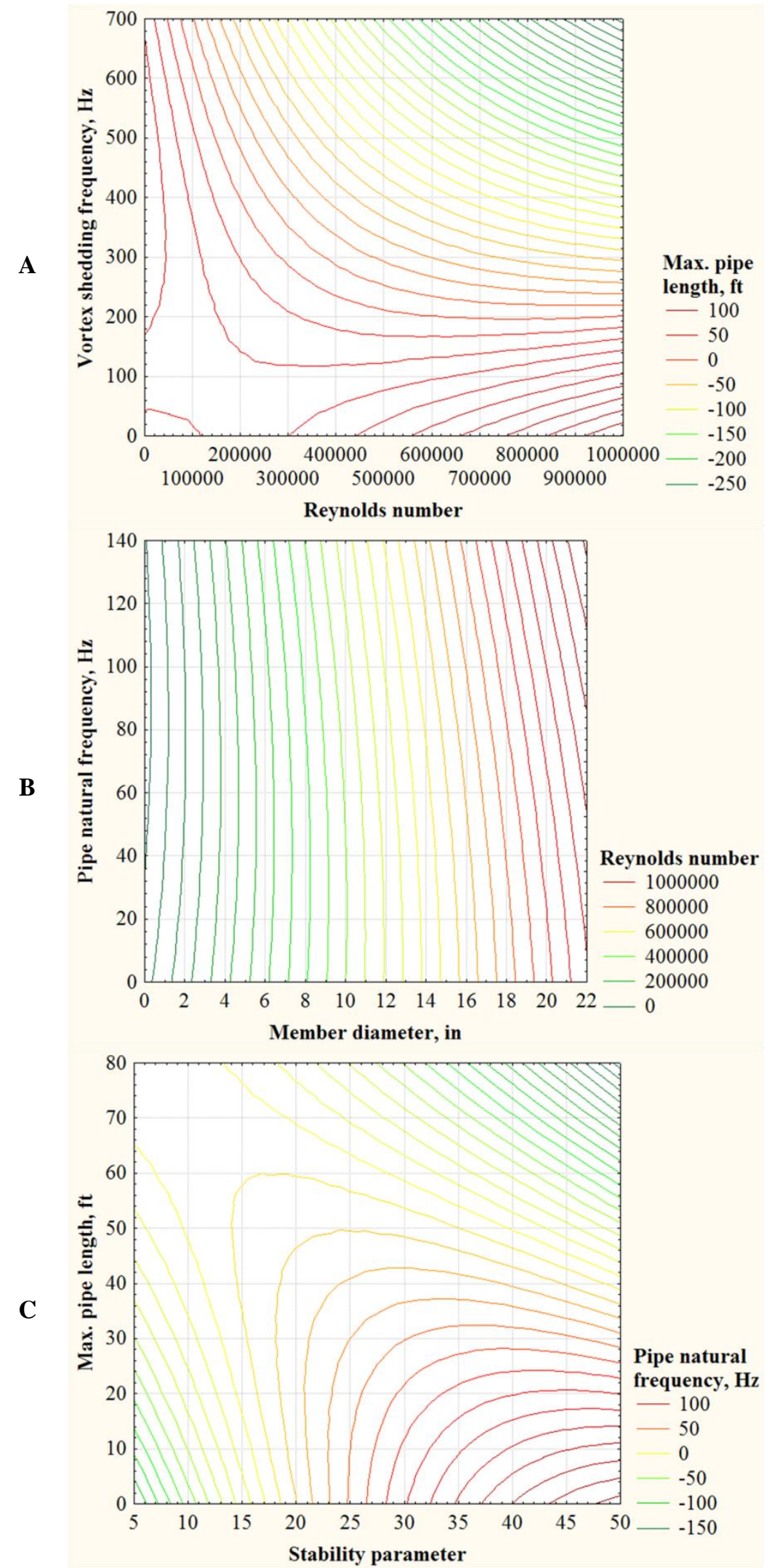

Figure 2 - Graphical representation of the results of the eighth experimental condition: $A$ - the dependencies of the maximum pipe length from vortex shedding frequency and the Reynolds number; $B$ - the dependencies of the Reynolds number from the pipe natural frequency and the member (pipe) diameter; $\mathrm{C}$ the dependencies of the pipe natural frequency from the maximum pipe length and stability parameter. 


\begin{tabular}{l|lr|ll|ll} 
& ISRA (India) & $=\mathbf{1 . 3 4 4}$ & SIS (USA) & $=\mathbf{0 . 9 1 2}$ & ICV (Poland) & $=\mathbf{6 . 6 3 0}$ \\
Impact Factor: & ISI (Dubai, UAE) $=\mathbf{0 . 8 2 9}$ & PUHL (Russia) $=\mathbf{0 . 2 0 7}$ & PIF (India) & $=\mathbf{1 . 9 4 0}$ \\
& GIF (Australia) & $\mathbf{0 . 5 6 4}$ & ESJI (KZ) & $=\mathbf{4 . 1 0 2}$ & IBI (India) & $\mathbf{4 . 2 6 0}$ \\
& JIF & $=1.500$ & SJIF (Morocco) & $=\mathbf{2 . 0 3 1}$ & & \\
\hline
\end{tabular}
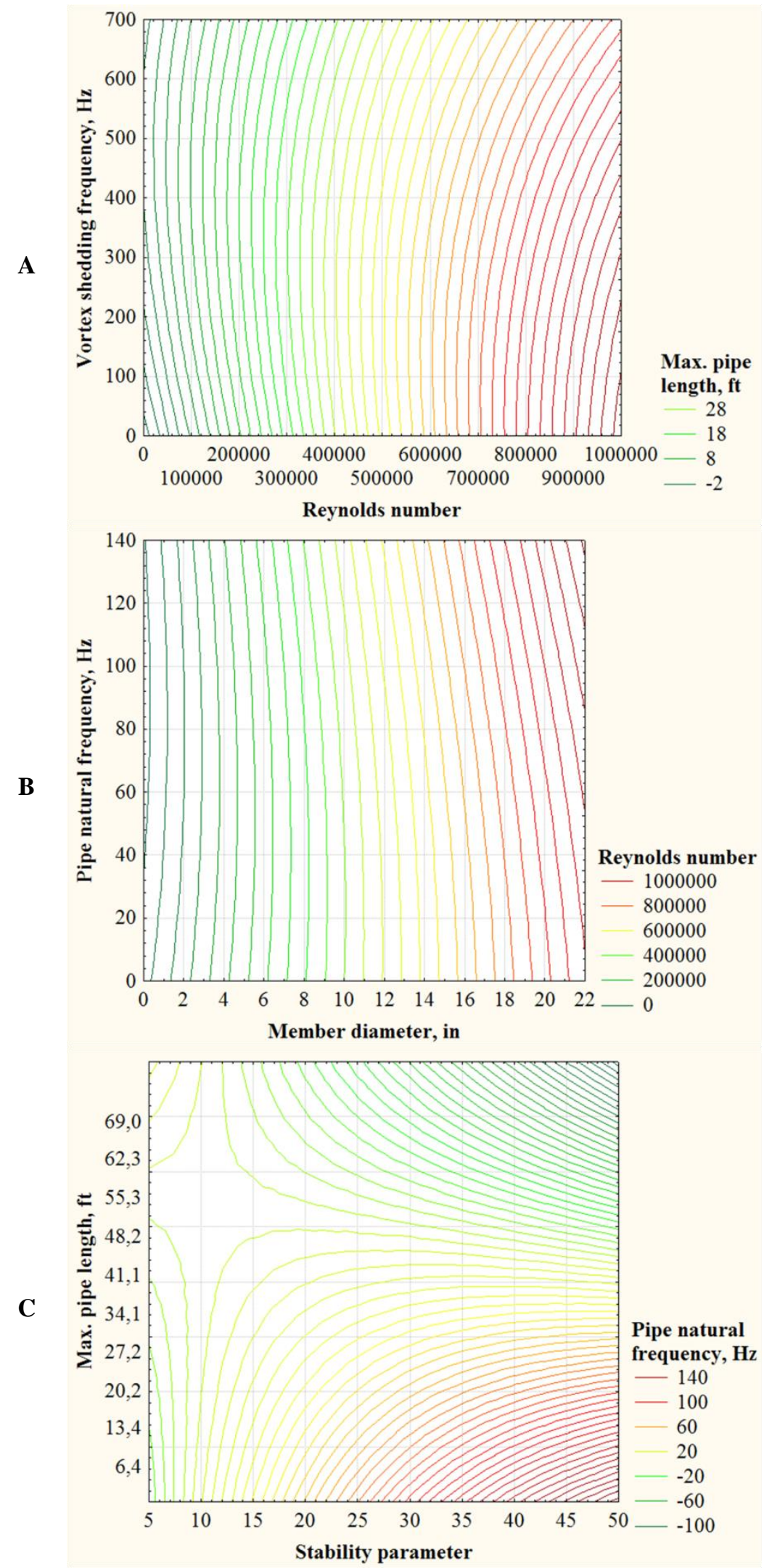

Figure 3 - Graphical representation of the results of the sixteenth experimental condition: $A$ - the dependencies of the maximum pipe length from vortex shedding frequency and the Reynolds number; $B$ the dependencies of the Reynolds number from the pipe natural frequency and the member (pipe) diameter; $\mathrm{C}$ - the dependencies of the pipe natural frequency from the maximum pipe length and stability parameter. 


\begin{tabular}{l|lr|ll|ll} 
& ISRA (India) & $=\mathbf{1 . 3 4 4}$ & SIS (USA) & $=\mathbf{0 . 9 1 2}$ & ICV (Poland) & $=\mathbf{6 . 6 3 0}$ \\
Impact Factor: & ISI (Dubai, UAE) $=\mathbf{0 . 8 2 9}$ & PUHL (Russia) $=\mathbf{0 . 2 0 7}$ & PIF (India) & $=\mathbf{1 . 9 4 0}$ \\
& GIF (Australia) & $\mathbf{0 . 5 6 4}$ & ESJI (KZ) & $=\mathbf{4 . 1 0 2}$ & IBI (India) & $\mathbf{4 . 2 6 0}$ \\
& JIF & $=1.500$ & SJIF (Morocco) & $=\mathbf{2 . 0 3 1}$ & & \\
\hline
\end{tabular}

A

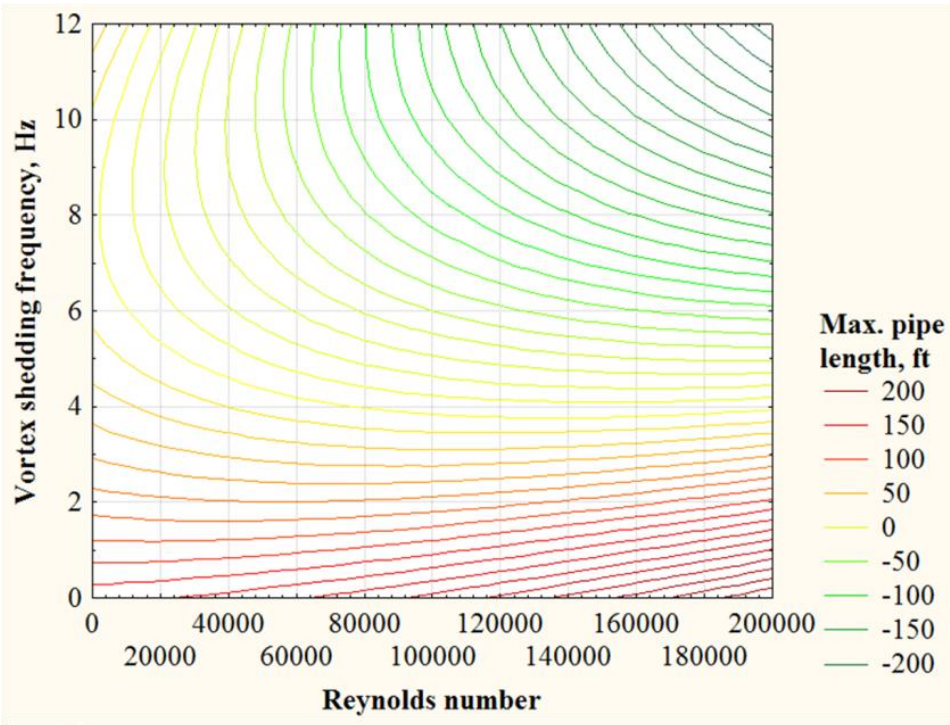

B
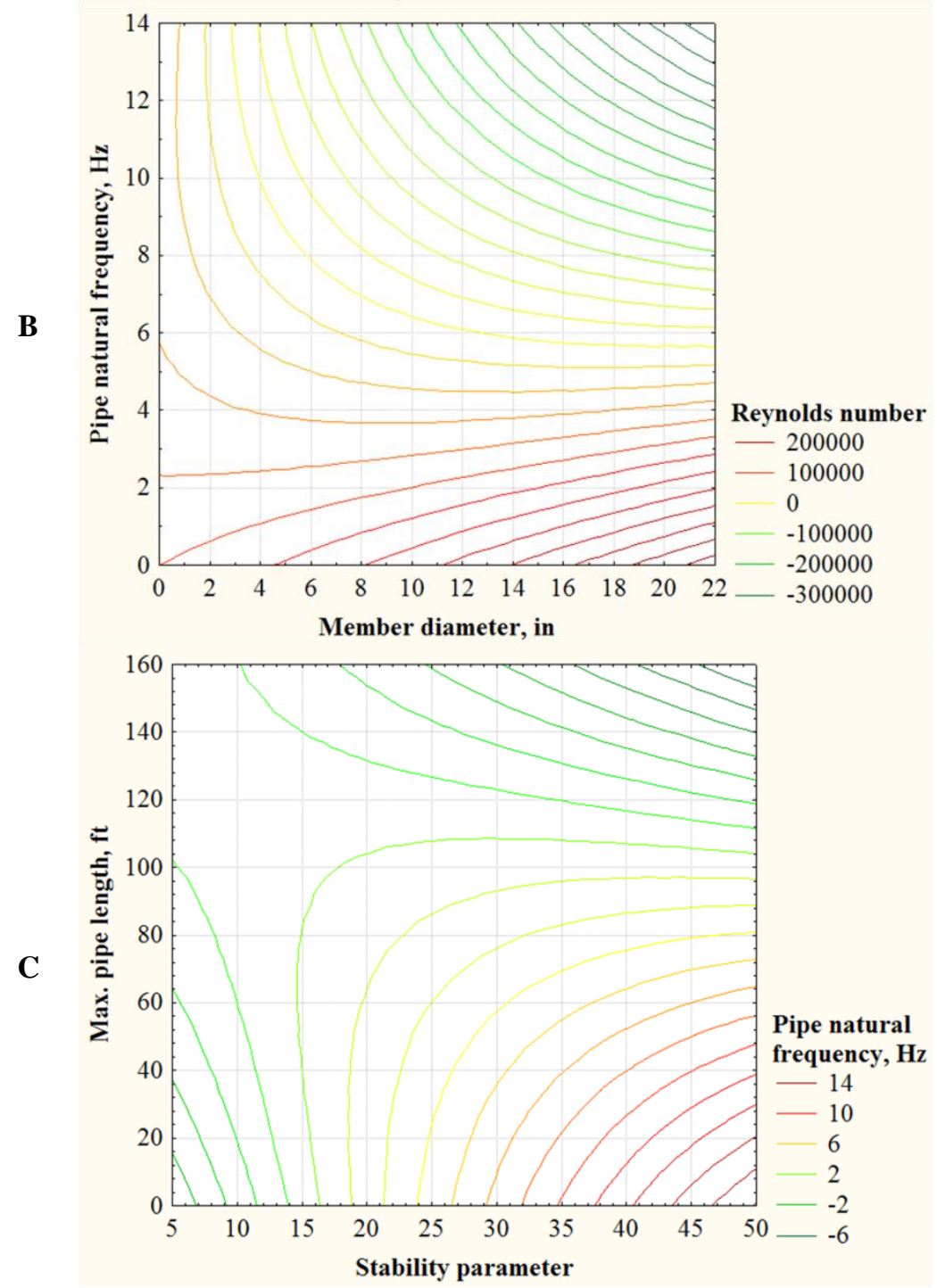

Figure 4 - Graphical representation of the results of the seventeenth experimental condition: $A$ - the dependencies of the maximum pipe length from vortex shedding frequency and the Reynolds number; $B$ the dependencies of the Reynolds number from the pipe natural frequency and the member (pipe) diameter; $\mathrm{C}$ - the dependencies of the pipe natural frequency from the maximum pipe length and stability parameter. 


\begin{tabular}{l|lr|ll|ll} 
& ISRA (India) & $=\mathbf{1 . 3 4 4}$ & SIS (USA) & $=\mathbf{0 . 9 1 2}$ & ICV (Poland) & $=\mathbf{6 . 6 3 0}$ \\
Impact Factor: & ISI (Dubai, UAE) $=\mathbf{0 . 8 2 9}$ & PUHL (Russia) $=\mathbf{0 . 2 0 7}$ & PIF (India) & $=\mathbf{1 . 9 4 0}$ \\
& GIF (Australia) & $\mathbf{0 . 5 6 4}$ & ESJI (KZ) & $=\mathbf{4 . 1 0 2}$ & IBI (India) & $\mathbf{4 . 2 6 0}$ \\
& JIF & $=1.500$ & SJIF (Morocco) & $=\mathbf{2 . 0 3 1}$ & & \\
\hline
\end{tabular}

A

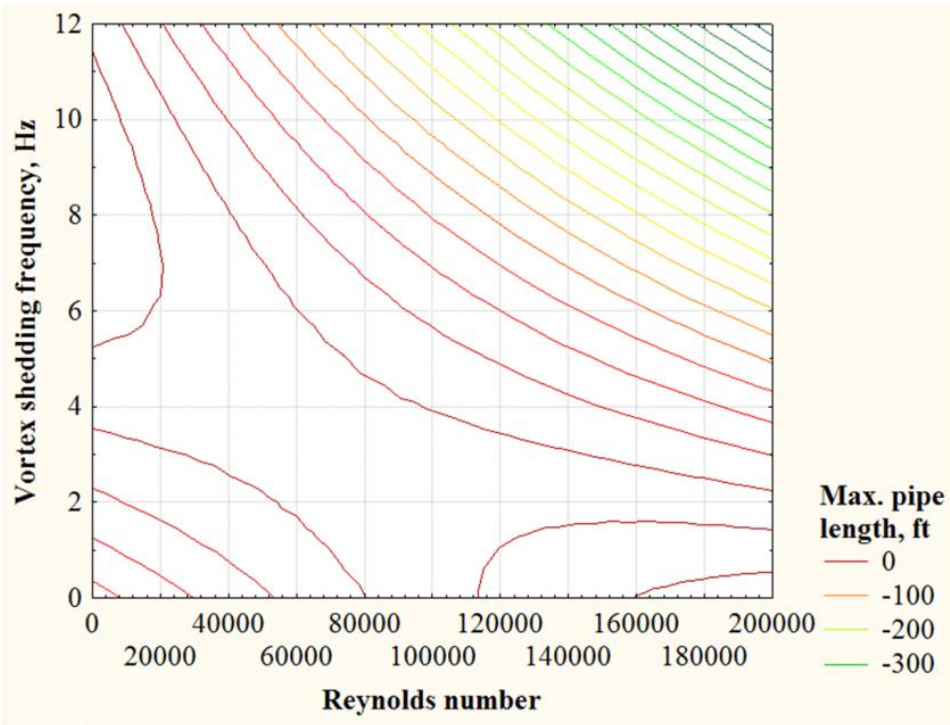

B
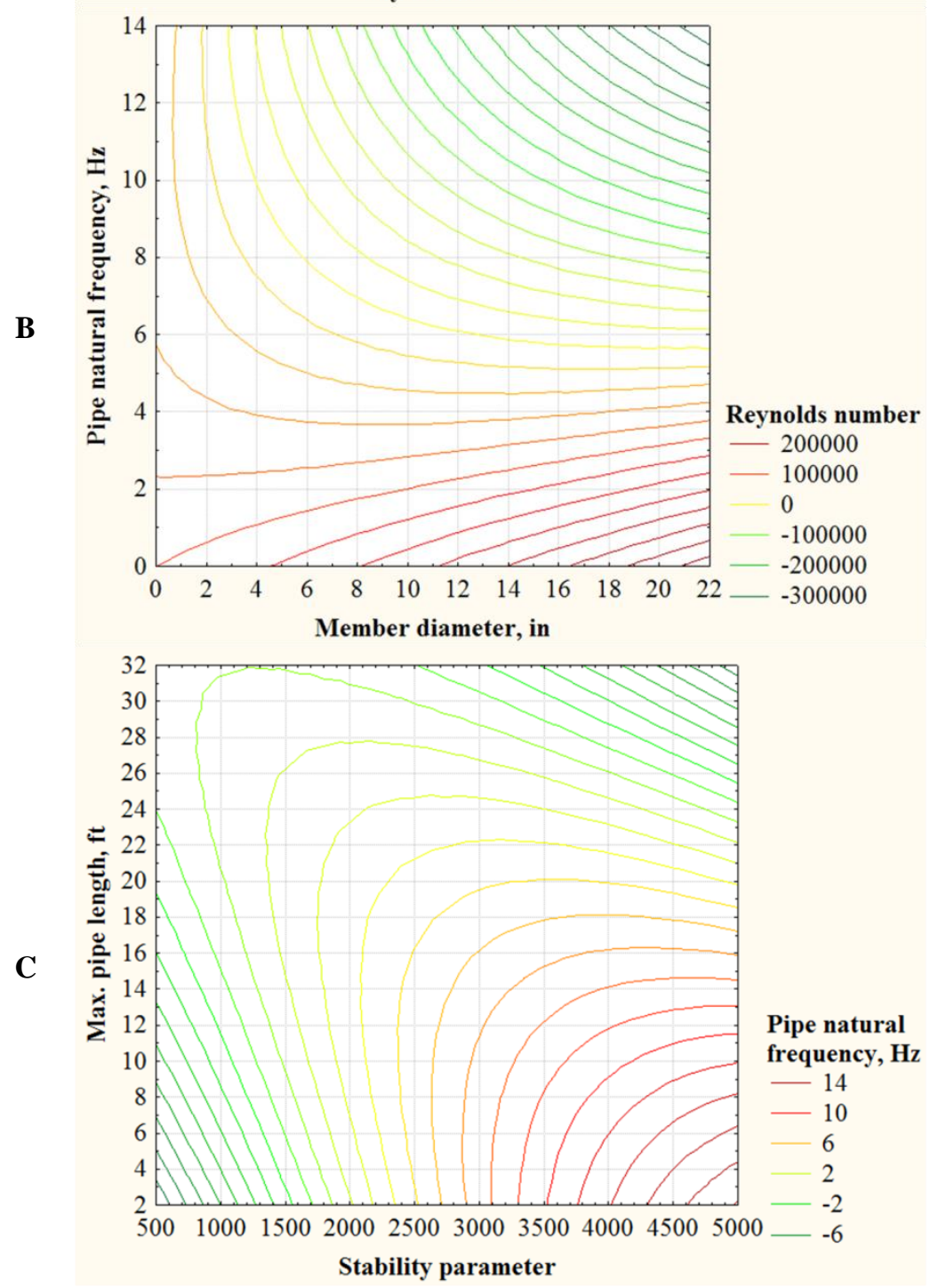

Figure 5 - Graphical representation of the results of the twenty-fifth experimental condition: $A$ - the dependencies of the maximum pipe length from vortex shedding frequency and the Reynolds number; $B$ the dependencies of the Reynolds number from the pipe natural frequency and the member (pipe) diameter; $\mathrm{C}$ - the dependencies of the pipe natural frequency from the maximum pipe length and stability parameter. 


\begin{tabular}{l|lr|ll|ll} 
& ISRA (India) & $=\mathbf{1 . 3 4 4}$ & SIS (USA) & $=\mathbf{0 . 9 1 2}$ & ICV (Poland) & $=\mathbf{6 . 6 3 0}$ \\
Impact Factor: & ISI (Dubai, UAE) $=\mathbf{0 . 8 2 9}$ & PUHL (Russia) $=\mathbf{0 . 2 0 7}$ & PIF (India) & $=\mathbf{1 . 9 4 0}$ \\
& GIF (Australia) & $\mathbf{0 . 5 6 4}$ & ESJI (KZ) & $=\mathbf{4 . 1 0 2}$ & IBI (India) & $\mathbf{4 . 2 6 0}$ \\
& JIF & $=1.500$ & SJIF (Morocco) & $=\mathbf{2 . 0 3 1}$ & & \\
\hline
\end{tabular}
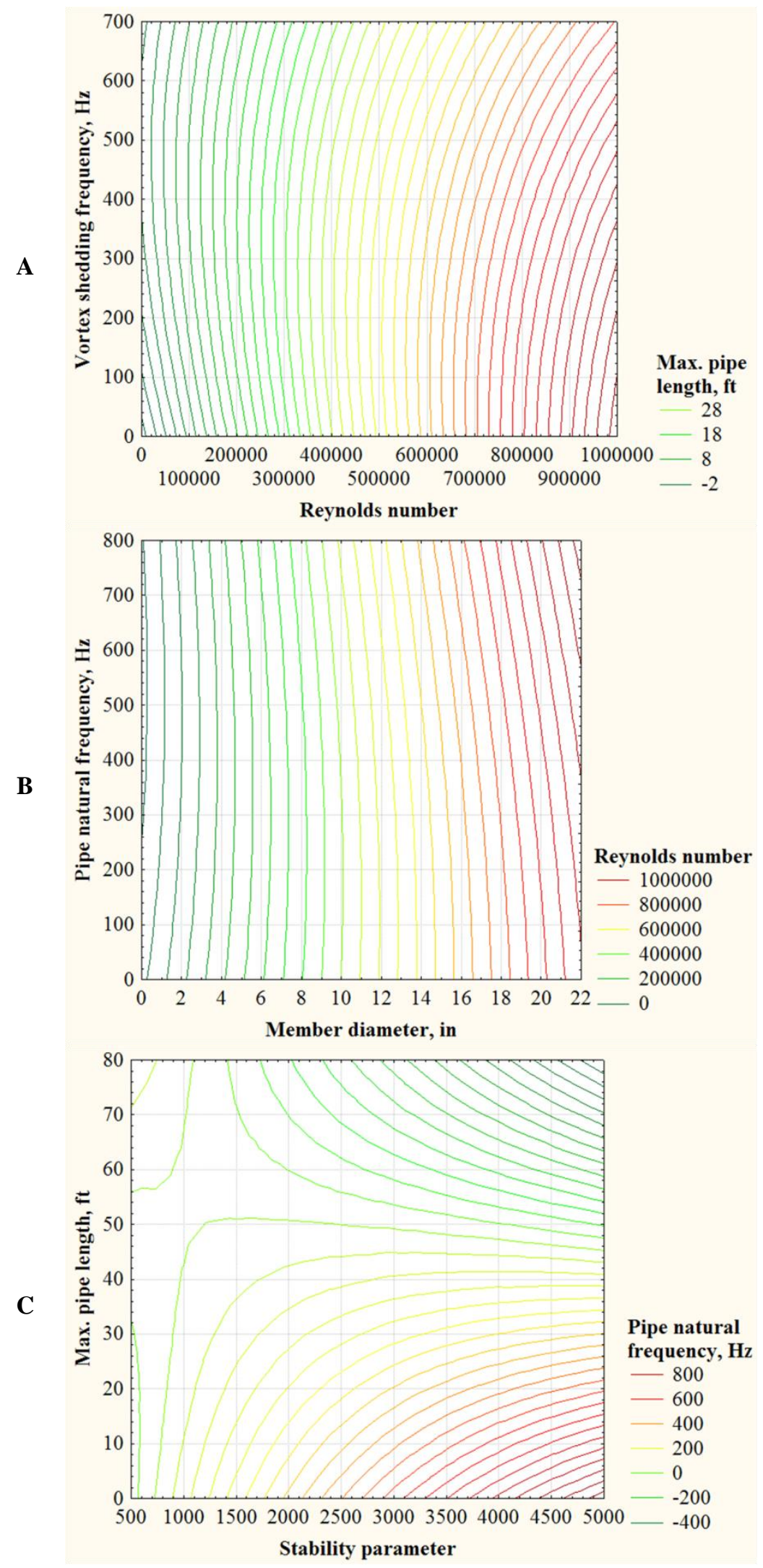

Figure 6 - Graphical representation of the results of the thirty-second experimental condition: $A$ - the dependencies of the maximum pipe length from vortex shedding frequency and the Reynolds number; $B$ the dependencies of the Reynolds number from the pipe natural frequency and the member (pipe) diameter; $\mathrm{C}$ - the dependencies of the pipe natural frequency from the maximum pipe length and stability parameter. 


\begin{tabular}{|c|c|c|c|c|c|c|}
\hline Impact Factor: & $\begin{array}{l}\text { ISRA (India) } \\
\text { ISI (Dubai, UAE } \\
\text { GIF (Australia) } \\
\text { JIF }\end{array}$ & $\begin{array}{l}=1.344 \\
=0.829 \\
=0.564 \\
=1.500\end{array}$ & $\begin{array}{l}\text { SIS (USA) } \\
\text { PИНЦ (Russia) } \\
\text { ESJI (KZ) } \\
\text { SJIF (Morocco) }\end{array}$ & $\begin{array}{l}=0.912 \\
=\mathbf{0 . 2 0 7} \\
=\mathbf{4 . 1 0 2} \\
=\mathbf{2 . 0 3 1}\end{array}$ & $\begin{array}{l}\text { ICV (Poland) } \\
\text { PIF (India) } \\
\text { IBI (India) }\end{array}$ & $\begin{array}{l}=6.630 \\
=1.940 \\
=4.260\end{array}$ \\
\hline
\end{tabular}

- the Reynolds number from the pipe natural frequency and the member (pipe) diameter;

- the pipe natural frequency from the maximum pipe length and stability parameter.

Analysis of the graphs makes possibility to choose the length of the pipe between two points of support at appropriate frequencies of vortex of air flow.

By analyzing the results of the first, the eighth, the sixteenth, the seventeenth, the twenty-fifth and the thirty-second experimental conditions, it was determined that values of safety factor and material damping don't affect on occurrence of resonance in the pipe. Therefore, damage of the pipe material is unlikely.

According to the first experimental condition of multi-factor experiment (the Fig. 1, A) it is possible to write the dependence of vortex shedding frequency of air flow from the Reynolds number (1)

$$
f_{v s}=\sqrt{\frac{\left(a^{2}-R_{e}^{2}\right) \cdot b^{2}}{a^{2}}}
$$

where $a$ and $b-$ axes of ellipse, because the dependence is elliptic.

At maximum values of specified design wind velocity, wind reference elevation and the Strouhal number (the eighth, the sixteenth and the thirtysecond experimental conditions), occurrence of resonance it is possible at the pipe diameter of more than 17 inches and the Reynolds number of more than 600000 (the Fig. 2-3-6, B). At minimum values of the considered parameters, resonance in the pipe doesn't observe (the Fig. 1-4-5, B). as (2)

Stability parameter of the steel pipe is defined

$$
K_{s}=\frac{4 \pi m \zeta}{\rho D^{2}}
$$

where $m$ - mass of the unit length, $\zeta-$ material critical damping ratio, $\rho$ - mass density of air.

Vibrations are not significant and don't lead to damage of the steel pipe when $K_{s}>25$. According to the results of the first and the seventeenth experimental conditions it was determined that critical value of stability parameter is achieved at the pipe natural frequency about $2 \mathrm{~Hz}$. With increasing of safety factor from 0.2 to 1.2 , critical value of stability parameter was determined at the pipe natural frequency about $6 \mathrm{~Hz}$. By accepting maximum values of the specified parameters, critical value of stability parameter was calculated at the pipe natural frequency:

- more than $30 \mathrm{~Hz}$, if safety factor of the pipe material is 1.2 ;

- up to $20 \mathrm{~Hz}$, if safety factor of the pipe material is 0.2 .

\section{Conclusions}

Based on the performed analysis of the results of multi-factor experiment it is possible to draw the following conclusions:

1. Calculated values of material damping and safety factor are less affected on vibration of the pipe.

2. Increasing of air flow velocity leads to increasing of vortex intensity which affects on stability of the steel pipe.

3. Calculated values of the length of the pipe section (not fixed) are critical, because on these sections there are significant vibrations, frequency of which may coincide with frequency of external vortices of air flow. In this regard, it is necessary to observe ratio of the length and the diameter of the steel pipe.

\section{References:}

1. Chemezov D (2017) The finite element modeling of the fluid flow in the pipelines with the complex local hydraulic resistances. ISJ Theoretical \& Applied Science, 01 (45): 14-38. Soi: http://s-o-i.org/1.1/TAS-01-45-4 Doi: https://dx.doi.org/10.15863/TAS.2017.01.45.4

2. Chemezov D (2016) The character of the fluid flow in the pipelines with the local hydraulic resistances. ISJ Theoretical \& Applied Science, 12 (44): 62-68. Soi: http://s-o-i.org/1.1/TAS-1244-13 Doi: http://dx.doi.org/10.15863/TAS.2016.12.44.13

3. Jain AB (2012) Vortex-Induced Vibrations of an Inclined Cylinder in Flow. Masters Theses 1911 - February 2014.
4. (2018) Vortex-induced vibration. Available: https://en.wikipedia.org/wiki/Vortexinduced_vibration (Accessed: 22.03.2018).

5. (2018) $2^{\mathrm{k}}$ Factorial Experiments. Available: http://eesemi.com/factorial-2k.htm (Accessed: 22.03.2018).

6. (2018) Strouhal number. Available: https://en.wikipedia.org/wiki/Strouhal_number (Accessed: 22.03.2018).

7. (2018) Damping ratio. Available: https://en.wikipedia.org/wiki/Damping_ratio (Accessed: 22.03.2018).

8. (2018) Factor of safety. Available: https://en.wikipedia.org/wiki/Factor_of_safety (Accessed: 22.03.2018). 